\title{
Thoracic Endometriosis presented as catamental hemoptysis: Fourteen Cases of a Rare Disease and the hormonal treatment management
}

\section{Yi Dai}

Peking Union Medical College Hospital, Chinese Academy of Medical Science

\section{Meng-Hui Li}

Beijing Chaoyang Hospital, Affiliated to Capital University of Medical Science

\section{Yong-Jian Liu}

Peking Union Medical College Hospital, Chinese Academy of Medical Science

\section{Bing Liu}

Peking Union Medical College Hospital, Chinese Academy of Medical Science

\section{Yu-Shi Wu}

Peking Union Medical College Hospital \& Chinese Academy of Medical Science

Jing-He Lang

Peking Union Medical College Hospital, Chinese Academy of Medical Science

\section{Zhen-Yu Zhang}

Beijing Chaoyang Hospital, Affiliated to Capital University of Medical Science

Jin-hua Leng ( $\square$ lengjenny@vip.sina.com )

Peking Union Medical College Hospital

Research

Keywords: thoracic endometriosis, catamenial hemoptysis, hormonal treatment

Posted Date: January 6th, 2020

DOI: https://doi.org/10.21203/rs.2.20089/v1

License: (c) (i) This work is licensed under a Creative Commons Attribution 4.0 International License. Read Full License 


\section{Abstract}

Background: Thoracic endometriosis syndrome (TES) is a rare disease in which a functioning endometrial tissue is observed in the pleura, lung parenchyma, airways, or diaphragm. The optimal management of this disease remains a matter of debate Methods: Retrospective study in one university based tertiary care hospital between 1997 to 2017 . 14 women presented as $\mathrm{CH}$ diagnosed with thoracic endometriosis were included. The main outcome of measure was cessation or recurrence of the clinical manifestations of thoracic endometriosis. Baseline parameters were presented using descriptive statistics. For categorical variables, Pearson's chi-square tests or Fisher's exact tests was used as appropriate to describe the characteristic of thoracic endometriosis presented as $\mathrm{CH}$, and the long-term prognosis after hormonal treatment.

Results : The mean onset age of the 14 patients was $30.21 \pm 5.40$ years. Catamenial hemoptysis $(\mathrm{CH})$ was characteristic symptom of these patients, and most of patients (13/14, 92.9\%) had regular menstruation and only $42.9 \%(6 / 14)$ of the patients complained of different degrees of dysmenorrhea. All patients underwent chest computed tomography (CT) scan during menstruation and 2 or 3 weeks after menstruation, which showed the obvious shrinking or disappearance of the lesions. No active bleeding on bronchial mucosa were observed in patients with $\mathrm{CH}$, and the bronchoalveolar lavage (BAL) did not find the typical abnormality. All of patients were given $\mathrm{GnRH}-\mathrm{a}$ for 3 to 6 months, eleven of them were administered with COCs cyclically after GnRH-a. All patients were followed up and the median follow-up duration was 24 months. Hemoptysis recurrence was observed in one patient.

Conclusion: $\mathrm{CH}$ is a rare clinical entity of thoracic endometriosis, which has the typical cyclic manifestation with menstruation. The change of CT images during and after menstruation or the response to GnRHa were helpful for accurate diagnosis. Hormonal treatment with $\mathrm{GnRH}$-a followed by COCs cyclically could be employed as a choice of therapy for efficient management of thoracic endometriosis.

\section{Introduction}

Thoracic endometriosis syndrome (TES) is a rare disease in which a functioning endometrial tissue is observed in the pleura, lung parenchyma, airways, or diaphragm [1-4]. The clinical manifestations of thoracic endometriosis are catamenial pneumothorax (CP) [5], catamenial hemoptysis $(\mathrm{CH})$, catamenial hemothorax $(\mathrm{CHT})[6,7]$ and lung nodules [8]. Thoracic endometriosis dates back to as early as 1912 when the first case was documented [9].

Endometriosis is defined as the presence of endometrial tissue out of uterine cavity, $[10,11]$ and affects approximately 10$15 \%$ of reproductive age women [12]. The most common anatomical location of endometriosis is pelvic cavity, and it is rarely found in extra pelvic cavity [13]. The extragenital endometriosis represents $5-12 \%$ of endometriosis $[1,2]$ and has been reported in multiple organ and systems, such as urinary tract [14], brain [15], gastrointestinal tract [16] and lungs. Though the prevalence of endometriosis is around 15\% [17], the extragenital endometriosis represents $5 \%$ of the localizations [1], and the TES is very rare [13], and it is even rarer to have TES with catamental hemoptysis as the main clinical manifestation, so the prevalence and etiology of thoracic endometriosis is unknown as most data comes from simple case reports or short series [13]. The diagnosis of TES is easily delayed and confounded with other diseases.

Various modalities from long-term use of hormonal agents $[18,19]$ including androgen derivatives, gonadotropin-releasing hormone agonists ( $\mathrm{GnRH}-\mathrm{a})$, and oral contraceptives, to surgical resection such as chemical pleurodesis, pleurectomy, and segmental resection have been experimented in the treatment of TES [20,21]; however, the optimal management of this disease remains a matter of debate [1]. Here, we report 14 cases with a high level of clinical suspicion and characteristics with periodic changes of the lesions in the chest CT scan and their effective hormonal treatment and management.

\section{Material And Methods}

\section{Patients and methods}


Women presenting with $\mathrm{CH}$ were diagnosed with thoracic endometriosis from 1997 to 2017 in our University based tertiary hospital. We performed a retrospective study of medical records of these patients and gave them a call if they could not visit our institution in January 2019.

\section{Diagnosis at respiratory department}

All the patients were diagnosed first at the respiratory department. The physicians screened for infection (including bacterial, viral, fungal, Legionella and parasitic), tuberculosis, respiratory disease, autoimmune diseases, such as vasculitis, coagulation disorder and systemic tumors. After suspicion of above were ruled out, the patients were then consulted by gynecologist. Treatment and follow-up were conducted by gynecologist and respiratory doctors together.

\section{Laboratory examination}

Computed tomography (CT) scans were performed during menstruation and 2 or 3 weeks after menstruation. Bronchoscopy was recommended during menstruation when the patients presented with $\mathrm{CH}$. The patient's sputum, bronchoscopic lavage fluid and pleural drainage fluid were used for repeated cytological examination and pathogenic culture. All the patients accepted to undergo pelvic ultrasound scanning for the pelvic endometriosis, and serum CA125 and CA199 were also evaluated.

\section{Treatment protocols at gynecology department}

Medication was administered to patients, including GnRH-a, for 3-6 times, once a month, and followed by oral contraceptive pills (COC), cyclically, until the patients desired to become pregnant or wanted to stop medication. This study protocol was approved by the Institutional Review Board (IRB) of PUMCH (IRB no. JS-1532).

\section{Follow-up}

Patients were followed-up at regular 3 month of intervals after the symptoms were cured and discharged. Our primary objective was cessation or recurrence of the clinical manifestations of $\mathrm{CH}$.

\section{Statistical analysis}

Statistical Package for the Social Sciences (SPSS) 20.0 (SPSS Inc., USA) was used for statistical analysis. Baseline parameters were presented using descriptive statistics. For categorical variables, Pearson's chi-square tests or Fisher's exact tests was used as appropriate, and for continuous variables, independent sample T test or the Wilcoxon signed rank test was used. Statistical significance was set at $P<.05$.

\section{Results}

\section{The demographic characteristic of patients}

Patient demographic data is represented in Table 1. The average age was $30.21 \pm 5.40$ (23-42) years, the average serum CA125 was $33.36 \pm 25.43 \mathrm{U} / \mathrm{ml}$ and the average hemoglobin level was $124.79 \pm 9.86 \mathrm{G} / \mathrm{L}$. None of the patients had history of any pulmonary comorbidity such as tuberculosis and smoking, and none of them had remarkable medical history that could cause hemoptysis. Except two patients GOP0, four patients had a history of vaginal delivery, five had cesarean section, and 3 patients had 2 to 4 gravida but papa 0 . Eight patients had a history of induced abortion; and 5 patients had the history of cesarean section. Most of patients $(13 / 14,92.9 \%)$ had regular menstruation and $42.9 \%(6 / 14)$ of the patients complained of different degrees of dysmenorrhea. None of patient had the history of endometriosis operation, and only one patient pelvic ultrasound showed the adenomyosis.

\section{Clinical characteristics of hemoptysis}


The main manifestation of 14 patients was $\mathrm{CH}$, only 6 of total 14 (42.9\%) patients complained concomitant symptom, most of the symptom were chest discomfort on obviously consisted with the location of lesion. Only one patient with right lower lobe lesion complained of right chest pain and tightness, and none of patient's symptom caused physical limitation and unable to work. Typical symptom occurred during menstruation in all patients, during 3 to $72(17.07 \pm 5.24)$ months before attending to out clinic, and the duration was 2 to 7 days every time, which resolved spontaneously. The volume of hemoptysis was not heavy, the hemoglobin level of all the $\mathrm{CH}$ patients were normal.

All patients were admitted to the respiratory departments at first. They were screened for infections tuberculosis, respiratory disease, autoimmune diseases and systemic tumors and were all negative. The mean duration from onset of symptom to diagnosis was $17.07 \pm 5.24$ months (3-72 months).

\section{CT image, FBO, BAL and pathology}

All patients underwent CT scanning during menstruation period and 2 or 3 weeks after periods, and presumed pulmonary lesions could be observed in the CT scans during menstruation. The focal consolidation with a relatively well-defined margin and ground-glass opacity [Fig. $1(1 \mathrm{~A}, 2 \mathrm{~A}, 3 \mathrm{~A}, 4 \mathrm{~A}, 5 \mathrm{~A}, 6 \mathrm{~A}, 7 \mathrm{~A})$ ] was observed in $\mathrm{CT}$ scanning during menstruation in all patients. The location of the lesions in 7 patients were confined to the right lung, including the middle and lower lobe in five cases, the right superior lobe in two case. The lesion of 4 patients were located in left lung, and 3 patients were confined to the segments of both sides of the lung (Table 2). Conversely, CT scans performed 2 or 3 weeks after menstruation demonstrated marked improvement of pulmonary consolidation, especially ground-glass opacity [Fig. 1 (1B, 2B, 3B, 4B, $5 B, 6 B, 7 B)]$ in all patients in the same location of the involved segments as in the previous $C T$ scans performed during menstruation (Table 2). Considering the correlation between the episodes of hemoptysis and changes in the series of chest CT scan findings, the possible presence of thoracic endometriosis was suspected.

Eight patients underwent fiberoptic bronchoscopy, 5 of them underwent the FBO during menstruation and the other 3 patients underwent during menstrual interval, no specific active bleeding finding could help to locate the lesions. Moreover, BAL did not find the typical ectopic endometrial stromal or gland epithelial cells. In a patient with hemothorax, CT scan showed pleural effusion in the right chest.

\section{Treatment regimens}

All of patients were given $\mathrm{GnRH}-\mathrm{a}$ for 3-6 months at the beginning of therapy and all of patients were responded well to $\mathrm{GnRHa}$, the hemoptysis ceased during 2-3 doses of $\mathrm{GnRHa}$. Three patients stopped medical treatment for pregnancy after 3 doses of $\mathrm{GnRHa}$, two of them because of fertility requirement and conceived successfully 5 to 7 months respectively after of treatment with $\mathrm{GnRH}-\mathrm{a}$. One patient delivered a healthy baby and was breastfeeding for 6 months. The other 11 patients were followed with COCs (drospirenone and ethinylestradiol tablets) after GnRHa for at least 6 months (6-70 months), until the patients desired to conceive or refused to take medicine. Only one patient refused to take oral medication after three doses of $\mathrm{GnRHa}$ completely relieved the hemoptysis symptoms, requiring follow-up observation.

\section{Follow up and relapse}

The average follow-up duration was 58.65 months (range 6-240 months). There was one case of recurrence, the recurrence rate is $7.1 \%(1 / 14)$. At the beginning of the treatment, pelvic ultrasound showed that the recurrent patient had adenomyosis. She ceased the treatment because of the plan for pregnancy after she took the 6 doses of GnRHa followed by 6 months of COCs. She succeeded in pregnancy and delivery, and in the 12 months of breastfeeding, had no relapse. After she stopped breastfeeding, her symptom of $\mathrm{CH}$ relapsed but were mild and she did not restart the treatment. After 9 years of $\mathrm{CH}$, she suffered from severe dysmenorrhea. The pelvic ultrasound suggested the severe adenomyosis and bilateral ovarian chocolate cyst. She accepted the hysterectomy and right appendectomy and left cystectomy. After the surgery her $\mathrm{CH}$ also disappear (Table 3). 


\section{Discussion}

Thoracic endometriosis is characteristic by functioning endometrial tissue in the pleura, lung parenchyma, airways, or diaphragm and was first described as early as 1912 by Hart [9]. Thoracic endometriosis is very rare and most of studies reporting it were either retrospective in design or case reports. To the best of our knowledge, here we reported the largest case series of thoracic endometriosis presented as $\mathrm{CH}$ in China. In our cohort, the mean age of presentation was 30.21 , which was similar with that reported in two large retrospective studies, that reported the peak incidence between 3034 years [22].

The symptoms of TES present clinically as one of the four entities: $\mathrm{CP}, \mathrm{CTH}, \mathrm{CH}$, or lung nodules. CP was the most common symptom reported for TES patients. As diagnosis of $\mathrm{CH}$ is more difficult, more patients are referred to our university-based tertiary care hospital than patients of CP. In the report of Hwang, also a single centered study, CH was presented in 8 of 15 thoracic endometriosis patients while only 7 were manifested as menstrual pneumothorax [23].

The pathogenesis of TES is not well understood [24]. One of explanation was thought to be the result of the filter function of the pulmonary vascular network with trapping of endometrial particles, which is a process similar to pulmonary embolism [25]. Previous obstetric or gynecological procedures (especially induced abortions), trauma, or manipulation of uterine tissue have been suggested to be a predisposing factor to microembolization of endometriotic cells and are considered to be a triggering effect in the development of TES [26]. Hemoptysis would be the consequence of rupturing of capillaries within the lesion due to fluid shift during menstruation [27]. Our analysis showed that 8 patients had a history of induced abortion and 5 had the history of cesarean section, which may be a plausible cause of TES. Other explanations for the spread of endometrial tissues to distant sites rest on hypotheses of venous or lymphatic circulation, or analogies to the metastatic spread of neoplasms [28]. Therefore, the hypothesis is that endometriosis also results from endometrial cells that are shed in the pelvic cavity and which have a tendency to implant and proliferate. In our 14 patients, only 2 patients were GOP0, but only one reported infertility. This was quite different with incidence of infertility (40-50\%) in pelvic endometriosis patients in other studies $[29,30]$. Most of our patients $(92.9 \%)$ had regular menstruation, and $42.9 \%$ of the patients complained of different degrees of dysmenorrhea. In previous studies by our team, we reported the incidence of dysmenorrhea in DIE patients as $91.0 \%$ and $61.6 \%$ in NON-DIE patients [31]. Even in the subgroup analysis of Chinese women in FEELING study (NCT01351051), we reported the incidence of dysmenorrhea as $71.5 \%$ in patients of OMA and $81.8 \%$ in patients of DIE [32]. So the pain associated with endometriosis in our 14 TES patients was not severe. Among the 14 patients, 13 patients had no clear evidence of pelvic endometriosis except for one patient complicated with adenomyosis and bilateral ovarian OMA, which was confirmed by surgery and pathology. So, in our analysis, we did not find the relationship of pelvic endometriosis and TES.

Diagnosis of TES could be challenging and majorly depends on clinical suspicion. The mean duration of our 14 patients from the onset of symptoms to the diagnosis was $17.07 \pm 5.24$ months and the concomitant symptom were not specific. However, the most important of the details of symptoms were recurrent with the menstruation, and the only cause of $\mathrm{CH}$ is pulmonary endometriosis (PEM), and especially the parenchymal form of endometriosis that leads to $\mathrm{CH}$ [33]. Bleeding may be caused by the pulmonary implants located in the pulmonary parenchyma or, more rarely, in the large airways, and neither massive hemoptysis nor deaths have been reported [24].

Chest radiography, $\mathrm{MRI}$ and bronchoscopy are some of the methods used to diagnose, however, due to the varying results there are limitation for their use in diagnosis of PEM [34, 35].

CT scan findings are nonspecific, which include ill-defined or well-defined ground-glass opacities, consolidation nodular lesions, thin-walled cavities, or bullous formations, pleural effusion and pneumothorax. The key feature of all the lesions, is their varying size and morphology over the menstrual cycle or their disappearance between menstruations. In all our $\mathrm{CH}$ cases, the lesion was detected clearly by CT scan and a corresponding repeat CT scan in the menstrual interval 
demonstrated marked improvement of pulmonary lesions in the same location of the involved segments. In fact, CT scan has a high diagnostic yield in TES with parenchymal involvement.

Although bronchoscopy has been suggested to have some additional value in this setting, the application is limited [36, 37]. Moreover, since PEM almost involved the distal pulmonary parenchyma rather than mucosa of the bronchi, bronchoscopy cannot localize the lesion in most cases, and the bleeding site may only be evident during menstruation [38]. In our study, 8 patients underwent fiberoptic bronchoscopy; no specific active bleeding finding could help to locate the lesions. Histological examination is considered to be the golden standard; however, it is very difficult to perform. A definite histological examination can be conducted only in one-third of the cases $[39,40]$.

Currently, there are no treatment guidelines for TES and little is known about the most appropriate treatment and patient outcomes. Since there has been no report of massive hemoptysis or mortality from catamenial hemoptysis, observation alone without medical or surgical treatment has been recommended by some clinicians, because hemoptysis tends to disappear spontaneously and appears to be clinically insignificant [41]. An important therapeutic alternative for TES is hormonal suppression with drugs such as danazol, oral contraceptives and $\mathrm{GnRH}-\mathrm{a}$, which has been a successful treatment option for TES without recurrence after its withdrawal [19, 42]. GnRHa is the gold standard for treatment of endometriosis which can reduce the level of estrogen to the condition of menopause rapidly. So, the response of the patients symptom to $\mathrm{GnRHa}$ could also aid in diagnosis. GnRH-a possess a few metabolic side effects and the efficacy depends on the degree of ovarian suppression [43]. The side effects are limited to the long term use of $\mathrm{GnRHa}$ in these patients. It is reported that the recurrence rate after stopping medicine exceeds $50 \%$ [44]. So, after GnRHa for long term management of TES patients is the core of the medicine therapy.

The most inspirited result of our cases is that there were only one cases of recurrence after a mean follow-up of 58.65 months, recurrence rate was $7.1 \%$. The recurrence happened in no hormonal treatment after delivery and breastfeeding. COCs with a dominant action of progestogen effectively influences endometriosis-related pain symptoms [45]. Indeed, the Royal College of Obstetrician Gynecologists recommends COCs as drugs of choice for treating symptoms of endometriosis and it is suitable for women who are surgically treated for endometrioma in order to avoid recurrence and subsequent surgery [46]. This is considered as a safe and economical treatment. So, we believe COCs could be the first choice for long term use in these patients. Recently, there were reports of Dienogest in the TES patient recurrent after surgery [4] and the patient with cerebral endometriosis [15]. Dienogest could be the choice of medicine in long term management of TES patients. Further studies are needed for stronger evidence. Second, pregnancy is also a kind of hormonal treatment of $\mathrm{CH}$. Three of our patients conceived, and all remained asymptomatic throughout pregnancy.

Therapy also could be achieved by video-assisted thoracoscopic surgery (VATS) [47-49] but there still recurrence is reported after VATS and now pharmacotherapy is considered to be the first line of therapy. Better knowledge about this disease among specialists in emergency medicine, pneumology, gynecology, and internal medicine is mandatory for early diagnosis and prevention of recurrence of thoracic endometriosis [26].

\section{Conclusion}

TES is a challenging disorder as the etiology and pathogenesis is still not well understood. $\mathrm{CH}$ is a rare clinical entity of thoracic endometriosis, which has the typical cyclic manifestation with menstruation. The history and change of CT images during and after menstruation or the response to GnRHa were helpful for accurate diagnosis, especially after exclusion of other causes. Medical treatments with a long-term treatment aim to lower circulating estradiol concentrations, thereby inhibiting the proliferation of endometrial tissue. Hormonal treatment with $\mathrm{GnRH}-\mathrm{a}$ followed by COCs cyclically could be employed as a choice of therapy for efficient management of thoracic endometriosis.

\section{Declarations}


Ethical approval and consent to participate

This study protocol was approved by the Institutional Review Board (IRB) of PUMCH (IRB no. JS-1532). All patients received information on the purpose and conduct of this study, and provided written, informed consent.

\section{Consent for publication}

Not Applicable

\section{Data Sharing, Data Availability Statement, Data Citation}

The data that support the findings of this study are available on request from the corresponding author. The data are not publicly available due to privacy or ethical restrictions.

\section{Competing financial interest}

The authors declare that they have no competing interests.

\section{Funding}

National Key R\&D Program of China: 2017YFC1001200

\section{Author's contributions}

$\mathrm{J}-\mathrm{H}$. Leng is the guarantor of the article and takes responsibility for the content of the manuscript, and approved the final version Y. D contributed substantially to conception and design analysis, integrity of the data and accuracy of the analysis, drafted the article, and revised the final version. M-H L, Y-S W and B L contributed substantially to data and material

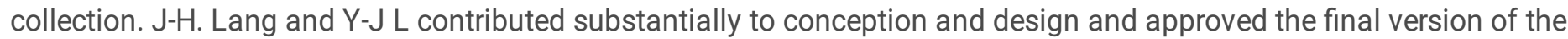
article. Z-Y Z contributed substantially to conception and design and approved the final version to be published. All authors read and approved the final version to be published.

\section{Acknowledgement}

The authors acknowledge Dr Anuradha Nalli (PhD) and Dr Amit Bhat (PhD) (Indegene, Bangalore, India) for providing language help in the development of this manuscript.

\section{References}

1. Leonardo-Pinto JP, Benetti-Pinto CL, Quagliato I, Yela DA. Hemoptysis and Endometriosis: An Unusual Association Case Report and Review of the Literature. Rev Bras Ginecol E Obstet Rev Fed Bras Soc Ginecol E Obstet. 2018 May;40(5):300-3.

2. Nair SS. Thoracic Endometriosis Syndrome: A Veritable Pandora's Box. J Clin Diagn Res [Internet]. 2016 [cited 2019 Apr 9]; Available from: http://jcdr.net/article_fulltext.asp?issn=0973-

709x\&year=2016\&volume=10\&issue=4\&page=QR04\&issn=0973-709x\&id=7700

3. Merlot B, Ploteau S, Abergel A, Rubob C, Hocke C, Canis M, et al. [Extragenital endometriosis: Parietal, thoracic, diaphragmatic and nervous lesions. CNGOF-HAS Endometriosis Guidelines]. Gynecol Obstet Fertil Senol. 2018 Mar;46(3):319-25.

4. Maniglio P, Ricciardi E, Meli F, Vitale SG, Noventa M, Vitagliano A, et al. Catamenial pneumothorax caused by thoracic endometriosis. Radiol Case Rep. 2018 Feb;13(1):81-5.

5. Junejo SZ, Singh Lubana S, Shina SS, Tuli SS. A Case of Thoracic Endometriosis Syndrome Presenting with Recurrent Catamenial Pneumothorax. Am J Case Rep. 2018 May 17;19:573-6. 
6. Chao Y-K, Ko P-J, Yeow K-M, Liu Y-H. Video-assisted Thoracoscopic Surgery for Catamenial Hemoptysis: the Rationale of Preoperative Computed Tomography-guided Hook-wire Localization: Surg Laparosc Endosc Percutan Tech. 2006 Dec;16(6):437-8.

7. Pankratjevaite L, Samiatina-Morkuniene D. A case report of thoracic endometriosis - A rare cause of haemothorax. Int $J$ Surg Case Rep. 2017;33:139-42.

8. Channabasavaiah AD, Joseph JV. Thoracic endometriosis: revisiting the association between clinical presentation and thoracic pathology based on thoracoscopic findings in 110 patients. Medicine (Baltimore). 2010 May;89(3):183-8.

9. Hart C. Histologisch benigne metastasen vom bau eines adenomyoms 22 jahre nach exstirpation eines tumors der genitalien. Frankf Z Pathol. 1912;(10):78-90.

10. Kuznetsov L, Dworzynski K, Davies M, Overton C. Diagnosis and management of endometriosis: summary of NICE guidance. BMJ. 2017 Sep 6;j3935.

11. Hirsch M, Begum MR, Paniz É, Barker C, Davis CJ, Duffy J. Diagnosis and management of endometriosis: a systematic review of international and national guidelines. BJOG Int J Obstet Gynaecol. 2018 Apr;125(5):556-64.

12. Cooperative Group of Endometriosis, Chinese Society of Obstetrics and Gynecology, Chinese Medical Association. [Guideline for the diagnosis and treatment of endometriosis]. Zhonghua Fu Chan Ke Za Zhi. 2015 Mar;50(3):161-9.

13. Davis AC, Goldberg JM. Extrapelvic Endometriosis. Semin Reprod Med. 2017;35(1):98-101.

14. Lakhi N, Dun EC, Nezhat CH. Hematoureter due to endometriosis. Fertil Steril. 2014 Jun;101(6):e37.

15. Maniglio P, Ricciardi E, Meli F, Tomao F, Peiretti M, Caserta D. Complete remission of cerebral endometriosis with dienogest: a case report. Gynecol Endocrinol Off J Int Soc Gynecol Endocrinol. 2018 Oct;34(10):837-9.

16. Young S, Burns MK, DiFrancesco L, Nezhat A, Nezhat C. Diagnostic and treatment guidelines for gastrointestinal and genitourinary endometriosis. J Turk Ger Gynecol Assoc. 2017 Dec 15;18(4):200-9.

17. Olive DL, Schwartz LB. Endometriosis. N Engl J Med. 1993 Jun 17;328(24):1759-69.

18. Rosenberg SM, Riddick DH. Successful treatment of catamenial hemoptysis with danazol. Obstet Gynecol. 1981 Jan;57(1):130-2.

19. Seltzer VL, Benjamin F. Treatment of pulmonary endometriosis with a long-acting GnRH agonist. Obstet Gynecol. 1990 Nov;76(5 Pt 2):929-31.

20. Inoue T, Kurokawa Y, Kaiwa Y, Abo M, Takayama T, Ansai M, et al. Video-assisted thoracoscopic surgery for catamenial hemoptysis. Chest. 2001 Aug;120(2):655-8.

21. Choi SY, Kim CK, Park CB. Successful treatment of catamenial hemoptysis by video-assisted thoracoscopic surgery. Thorac Cardiovasc Surg. 2013 Jan;61(1):94-6.

22. Korom S, Canyurt H, Missbach A, Schneiter D, Kurrer MO, Haller U, et al. Catamenial pneumothorax revisited: clinical approach and systematic review of the literature. J Thorac Cardiovasc Surg. 2004 Oct;128(4):502-8.

23. Hwang SM, Lee CW, Lee BS, Park JH. Clinical features of thoracic endometriosis: A single center analysis. Obstet Gynecol Sci. 2015;58(3):223.

24. Alifano M, Trisolini R, Cancellieri A, Regnard JF. Thoracic endometriosis: current knowledge. Ann Thorac Surg. 2006 Feb;81(2):761-9.

25. Park WW. The occurrence of decidual tissue within the lung; report of a case. J Pathol Bacteriol. 1954 Apr;67(2):56370.

26. Rousset-Jablonski C, Alifano M, Plu-Bureau G, Camilleri-Broet S, Rousset P, Regnard J-F, et al. Catamenial pneumothorax and endometriosis-related pneumothorax: clinical features and risk factors. Hum Reprod Oxf Engl. 2011 Sep;26(9):2322-9.

27. Foster DC, Stern JL, Buscema J, Rock JA, Woodruff JD. Pleural and parenchymal pulmonary endometriosis. Obstet Gynecol. 1981 Nov;58(5):552-6. 
28. Augoulea A, Lambrinoudaki I, Christodoulakos G. Thoracic endometriosis syndrome. Respir Int Rev Thorac Dis. 2008;75(1):113-9.

29. Brown J, Farquhar C. An overview of treatments for endometriosis. JAMA. 2015 Jan 20;313(3):296-7.

30. Giudice LC. Clinical practice. Endometriosis. N Engl J Med. 2010 Jun 24;362(25):2389-98.

31. Dai Y, Leng J-H, Lang J-H, Li X-Y, Zhang J-J. Anatomical distribution of pelvic deep infiltrating endometriosis and its relationship with pain symptoms. Chin Med J (Engl). 2012 Jan;125(2):209-13.

32. Dai Y, Zhou Y, Zhang X, Xue M, Sun P, Leng J, et al. Factors associated with deep infiltrating endometriosis versus ovarian endometrioma in China: a subgroup analysis from the FEELING study. BMC Womens Health. 2018 22;18(1):205.

33. Joseph J, Sahn SA. Thoracic endometriosis syndrome: new observations from an analysis of 110 cases. Am J Med. 1996 Feb;100(2):164-70.

34. Hilaris GE, Payne CK, Osias J, Cannon W, Nezhat CR. Synchronous rectovaginal, urinary bladder, and pulmonary endometriosis. JSLS. 2005 Mar;9(1):78-82.

35. Nezhat, C.R., Berger, G.S., Nezhat, F., Buttram, V.C.J., Nezhat, C.H. Endometriosis Advanced Management and Surgical Techniques. Springer;

36. Augoulea A, Lambrinoudaki I, Christodoulakos G. Thoracic endometriosis syndrome. Respir Int Rev Thorac Dis. 2008;75(1):113-9.

37. Guidry GG, George RB. Diagnostic studies in catamenial hemoptysis. Chest. 1990 Aug;98(2):260-1.

38. Nakashima Y, Shoji F, Osoegawa A, Yoshino I, Maehara Y. Catamenial hemoptysis treated by video-assisted thoracic surgery: report of a case. Surg Today. 2011 May;41(5):701-3.

39. Lu M-S, Liu Y-H, Wu Y-C, Hsieh M-J, Liu H-P. What we see is not what we get in catamenial haemoptysis. Int J Clin Pract. 2006 Feb;60(2):232-3.

40. Nezhat C, King LP, Paka C, Odegaard J, Beygui R. Bilateral thoracic endometriosis affecting the lung and diaphragm. JSLS. 2012 Mar;16(1):140-2.

41. Ryu J-S, Song E-S, Lee K-H, Cho JH, Kwak S-M, Lee HL. Natural history and therapeutic implications of patients with catamenial hemoptysis. Respir Med. 2007 May;101(5):1032-6.

42. Wood DJ, Krishnan K, Stocks P, Morgan E, Ward MJ. Catamenial haemoptysis: a rare cause. Thorax. 1993 Oct;48(10):1048-9.

43. Zito G, Luppi S, Giolo E, Martinelli M, Venturin I, Di Lorenzo G, et al. Medical Treatments for Endometriosis-Associated Pelvic Pain. BioMed Res Int. 2014;2014:1-12.

44. Prentice A. Regular review: Endometriosis. BMJ. 2001 Jul 14;323(7304):93-5.

45. Schindler AE. Non-contraceptive benefits of oral hormonal contraceptives. Int J Endocrinol Metab. 2013;11(1):41-7.

46. Haider Z, D'Souza R. Non-contraceptive benefits and risks of contraception. Best Pract Res Clin Obstet Gynaecol. 2009 Apr;23(2):249-62.

47. Alifano M, Trisolini R, Cancellieri A, Regnard JF. Thoracic endometriosis: current knowledge. Ann Thorac Surg. 2006 Feb;81(2):761-9.

48. Inoue T, Kurokawa Y, Kaiwa Y, Abo M, Takayama T, Ansai M, et al. Video-assisted thoracoscopic surgery for catamenial hemoptysis. Chest. 2001 Aug;120(2):655-8.

49. Haruki T, Fujioka S, Adachi Y, Miwa K, Taniguchi Y, Nakamura H. Successful Video-Assisted Thoracic Surgery for Pulmonary Endometriosis: Report of a Case. Surg Today. 2007 Jan 25;37(2):141-4.

\section{Tables}

\section{Table 1: Patient demographic data}




\begin{tabular}{|c|c|c|c|c|c|c|c|c|c|}
\hline$)$ & $\begin{array}{c}\text { Age } \\
\text { (years) }\end{array}$ & $\begin{array}{c}\text { Main } \\
\text { manifestation }\end{array}$ & $\begin{array}{l}\text { Accompanying } \\
\text { symptom }\end{array}$ & $\mathrm{G} / \mathrm{P}$ & $\begin{array}{l}\text { Uterine } \\
\text { operation }\end{array}$ & Menstruation & Dysmenorrhea & $\begin{array}{l}\text { Coexisting } \\
\text { EMT }\end{array}$ & CA125 \\
\hline & 29 & $\mathrm{CH}$ & $\begin{array}{c}\text { chest } \\
\text { discomfort }\end{array}$ & $\begin{array}{l}2 / 1 \\
(\mathrm{C})\end{array}$ & $\begin{array}{l}\text { Curettage } \\
\text { and } \\
\text { cesarean } \\
\text { section }\end{array}$ & Regular & None & & 26.10 \\
\hline & 26 & $\mathrm{CH}$ & No & $0 / 0$ & None & Regular & dysmenorrhea & $\begin{array}{l}\text { adenomyosis, } \\
\text { bilateral OMA }\end{array}$ & 109.30 \\
\hline & 24 & $\mathrm{CH}$ & No & $\begin{array}{l}1 / 1 \\
(\mathrm{C})\end{array}$ & $\begin{array}{l}\text { cesarean } \\
\text { section }\end{array}$ & Regular & dysmenorrhea & & 32.20 \\
\hline & 34 & $\mathrm{CH}$ & No & $\begin{array}{l}5 / 2 \\
(V)\end{array}$ & Curettage & Oligomenorrhea & None & & 15.50 \\
\hline & 23 & $\mathrm{CH}$ & $\begin{array}{c}\text { right chest } \\
\text { pain and chest } \\
\text { tightness }\end{array}$ & $\begin{array}{l}1 / 1 \\
(\mathrm{C})\end{array}$ & $\begin{array}{l}\text { Cesarean } \\
\text { section }\end{array}$ & Regular & None & & 20.10 \\
\hline & 36 & $\mathrm{CH}$ & No & $\begin{array}{l}2 / 1 \\
(C)\end{array}$ & $\begin{array}{l}\text { Curettage } \\
\text { and } \\
\text { cesarean } \\
\text { section }\end{array}$ & Regular & dysmenorrhea & & 14.50 \\
\hline & 29 & $\mathrm{CH}$ & No & $2 / 0$ & Curettage & Regular & None & & 16.70 \\
\hline & 25 & $\mathrm{CH}$ & NO & $0 / 0$ & None & Regular & dysmenorrhea & & 38.00 \\
\hline & 26 & $\mathrm{CH}$ & $\begin{array}{c}\text { chest } \\
\text { discomfort }\end{array}$ & $4 / 0$ & Curettage & Regular & dysmenorrhea & & 56.00 \\
\hline 5 & 29 & $\mathrm{CH}$ & $\begin{array}{c}\text { bilateral chest } \\
\text { pain }\end{array}$ & $2 / 0$ & Curettage & Regular & None & & 23.00 \\
\hline T & 33 & $\mathrm{CH}$ & No & $\begin{array}{l}3 / 1 \\
(V)\end{array}$ & Curettage & Regular & None & & 29.00 \\
\hline 2 & 42 & $\mathrm{CH}$ & $\begin{array}{c}\text { Chest } \\
\text { discomfort }\end{array}$ & $\begin{array}{l}4 / 1 \\
(V)\end{array}$ & Curettage & Regular & None & & 32.00 \\
\hline 3 & 35 & $\mathrm{CH}$ & $\begin{array}{c}\text { Chest } \\
\text { discomfort }\end{array}$ & $\begin{array}{l}4 / 1 \\
(\mathrm{C})\end{array}$ & $\begin{array}{l}\text { Curettage } \\
\text { and } \\
\text { cesarean } \\
\text { section }\end{array}$ & Regular & dysmenorrhea & & 21.24 \\
\hline$\overline{7}$ & 32 & $\mathrm{CH}$ & No & $\begin{array}{l}4 / 1 \\
(V)\end{array}$ & Curettage & Regular & None & & 21.10 \\
\hline
\end{tabular}

$\mathrm{CH}$ : Catamenial hemoptysis; EMT: endometriosis; OMA: ovarian endometrioma

Table 2: Pathological findings of CT scan reports 


\begin{tabular}{|c|c|c|c|c|c|}
\hline $\begin{array}{l}\text { Patient } \\
\text { No. }\end{array}$ & $\begin{array}{c}\text { Main } \\
\text { manifestation }\end{array}$ & $\begin{array}{c}\text { CT (during } \\
\text { menstruation区 }\end{array}$ & FOB & BAL & Pathology \\
\hline 1 & $\mathrm{CH}$ & LLL:GGO & $\begin{array}{c}\text { No specific finding in } \\
\text { menses }\end{array}$ & blood and phagocytes & $\begin{array}{l}\text { bloody } \\
\text { sputum }\end{array}$ \\
\hline 2 & $\mathrm{CH}$ & LLL:GGO & $\begin{array}{c}\text { No specific finding, after } \\
\text { menses }\end{array}$ & ND & $\begin{array}{l}\text { bloody } \\
\text { sputum }\end{array}$ \\
\hline 3 & $\mathrm{CH}$ & RLL:GGO & $\begin{array}{l}\text { No specific finding, in } \\
\text { menses }\end{array}$ & $\begin{array}{l}\text { blood and phagocytes (perls } \\
\text { stain }+ \text { ) }\end{array}$ & $\begin{array}{l}\text { bloody } \\
\text { sputum }\end{array}$ \\
\hline 4 & $\mathrm{CH}$ & LUL\&RUL:GGO & $\begin{array}{c}\text { No specific finding, in } \\
\text { menses }\end{array}$ & blood and phagocytes & $\begin{array}{l}\text { bloody } \\
\text { sputum }\end{array}$ \\
\hline 5 & $\mathrm{CH}$ & RLL:GGO & $\begin{array}{c}\text { No specific finding, in } \\
\text { menses }\end{array}$ & - & $\begin{array}{l}\text { bloody } \\
\text { sputum }\end{array}$ \\
\hline 6 & $\mathrm{CH}$ & RLL:GGO & $\begin{array}{c}\text { No specific finding, after } \\
\text { menses }\end{array}$ & - & $\begin{array}{l}\text { bloody } \\
\text { sputum }\end{array}$ \\
\hline 7 & $\mathrm{CH}$ & RML\&RLL:GGO & - & - & $\begin{array}{l}\text { bloody } \\
\text { sputum }\end{array}$ \\
\hline 8 & $\mathrm{CH}$ & RML:GGO & - & - & $\begin{array}{l}\text { bloody } \\
\text { sputum }\end{array}$ \\
\hline 9 & $\mathrm{CH}$ & RML\&LML:GGO & - & - & $\begin{array}{l}\text { bloody } \\
\text { sputum }\end{array}$ \\
\hline 10 & $\mathrm{CH}$ & RUL\&LUL:GGO & $\begin{array}{c}\text { No specific finding, after } \\
\text { menses }\end{array}$ & blood and phagocytes & $\begin{array}{l}\text { bloody } \\
\text { sputum }\end{array}$ \\
\hline 11 & $\mathrm{CH}$ & LML:GGO & $\begin{array}{c}\text { No specific finding, after } \\
\text { menses }\end{array}$ & blood and phagocytes & $\begin{array}{l}\text { bloody } \\
\text { sputum }\end{array}$ \\
\hline 12 & $\mathrm{CH}$ & RUL:GGO & - & - & $\begin{array}{l}\text { bloody } \\
\text { sputum }\end{array}$ \\
\hline 13 & $\mathrm{CH}$ & LLL:GGO & $\begin{array}{c}\text { No specific finding, in } \\
\text { menses }\end{array}$ & blood and phagocytes & $\begin{array}{l}\text { bloody } \\
\text { sputum }\end{array}$ \\
\hline 14 & $\mathrm{CH}$ & RUL:GGO & - & - & $\begin{array}{l}\text { bloody } \\
\text { sputum }\end{array}$ \\
\hline
\end{tabular}

FOB: Fiberoptic bronchoscopy BAL: Bronchoalveolar lavage; CT: Computed tomography; CH: Catamenial hemoptysis; ND: Not detected

\section{Table 3: Details of treatment regimens and their response}




\begin{tabular}{|c|c|c|c|c|c|c|c|}
\hline $\begin{array}{l}\text { Patient } \\
\text { No. }\end{array}$ & $\begin{array}{c}\text { Main } \\
\text { manifestation }\end{array}$ & $\begin{array}{l}\text { Interval } \\
\text { (months) }\end{array}$ & Treatment & $\begin{array}{l}\text { Response } \\
\text { to } \\
\text { treatment }\end{array}$ & $\begin{array}{c}\text { Follow- } \\
\text { up } \\
\text { (months) }\end{array}$ & Recurrence & $\begin{array}{l}\text { Treatment after } \\
\text { recurrence }\end{array}$ \\
\hline 1 & $\mathrm{CH}$ & 13 & $\mathrm{GnRHa} \times 3+\mathrm{COC} \times 21 \mathrm{~m}$ & no $\mathrm{CH}$ & 240 & No & - \\
\hline 2 & $\mathrm{CH}$ & 23 & $\mathrm{GnRHa} \times 6+\mathrm{COC} \times 6 \mathrm{~m}$ & no $\mathrm{CH}$ & 144 & No & - \\
\hline 3 & $\mathrm{CH}$ & 7 & $\mathrm{GnRHa} \times 6+\mathrm{COC} \times 6 \mathrm{~m}$ & no $\mathrm{CH}$ & 36 & Yes* & $\begin{array}{l}\text { hysterectomy and } \\
\text { right appendectomy } \\
\text { and left cystectomy }\end{array}$ \\
\hline 4 & $\mathrm{CH}$ & 12 & $\mathrm{GnRHa} \times 4+\mathrm{COC} \times 8 \mathrm{~m}$ & no $\mathrm{CH}$ & 17 & No & - \\
\hline 5 & $\mathrm{CH}$ & 3 & $\mathrm{GnRHa} \times 3+\mathrm{COC} \times 21 \mathrm{~m}$ & no $\mathrm{CH}$ & 24 & No & - \\
\hline 6 & $\mathrm{CH}$ & 10 & $\mathrm{GnRHa} \times 3+\mathrm{COC} \times 1 \mathrm{~m}$ & no $\mathrm{CH}$ & 24 & No & - \\
\hline 7 & $\mathrm{CH}$ & 1 & $\mathrm{GnRHa} \times 3$ & no $\mathrm{CH}$ & 12 & No & - \\
\hline 8 & $\mathrm{CH}$ & 12 & $\mathrm{GnRHa} \times 3^{*}$ & no $\mathrm{CH}$ & 51 & No & - \\
\hline 9 & $\mathrm{CH}$ & 17 & $\mathrm{GnRHa} \times 3^{*}$ & no $\mathrm{CH}$ & 48 & No & - \\
\hline 10 & $\mathrm{CH}$ & 10 & $\mathrm{GnRHa} \times 6+\mathrm{COC} \times 9 \mathrm{~m}$ & no $\mathrm{CH}$ & 52 & No & - \\
\hline 11 & $\mathrm{CH}$ & 72 & $\mathrm{GnRHa} \times 6+\mathrm{COC} \times 6 \mathrm{~m}$ & no $\mathrm{CH}$ & 44 & No & - \\
\hline 12 & $\mathrm{CH}$ & 3 & $\mathrm{GnRHa} \times 6+\mathrm{COC} \times 6 \mathrm{~m}$ & no $\mathrm{CH}$ & 53 & No & - \\
\hline 13 & $\mathrm{CH}$ & 48 & $\mathrm{GnRHa} \times 3+\mathrm{COC} \times 70 \mathrm{~m}$ & no $\mathrm{CH}$ & 70 & No & - \\
\hline 14 & $\mathrm{CH}$ & 6 & $\mathrm{GnRHa} \times 3+\mathrm{COC} \times 6 \mathrm{~m}$ & no $\mathrm{CH}$ & 6 & No & - \\
\hline
\end{tabular}

CH: Catamenial hemoptysis GnRHa: Gonadotropin-releasing hormone agonists; COC: Combined oral contraceptives; ${ }^{*}$ conceived successfully after of treatment with $\mathrm{GnRH}-\mathrm{a}$

\section{Figures}




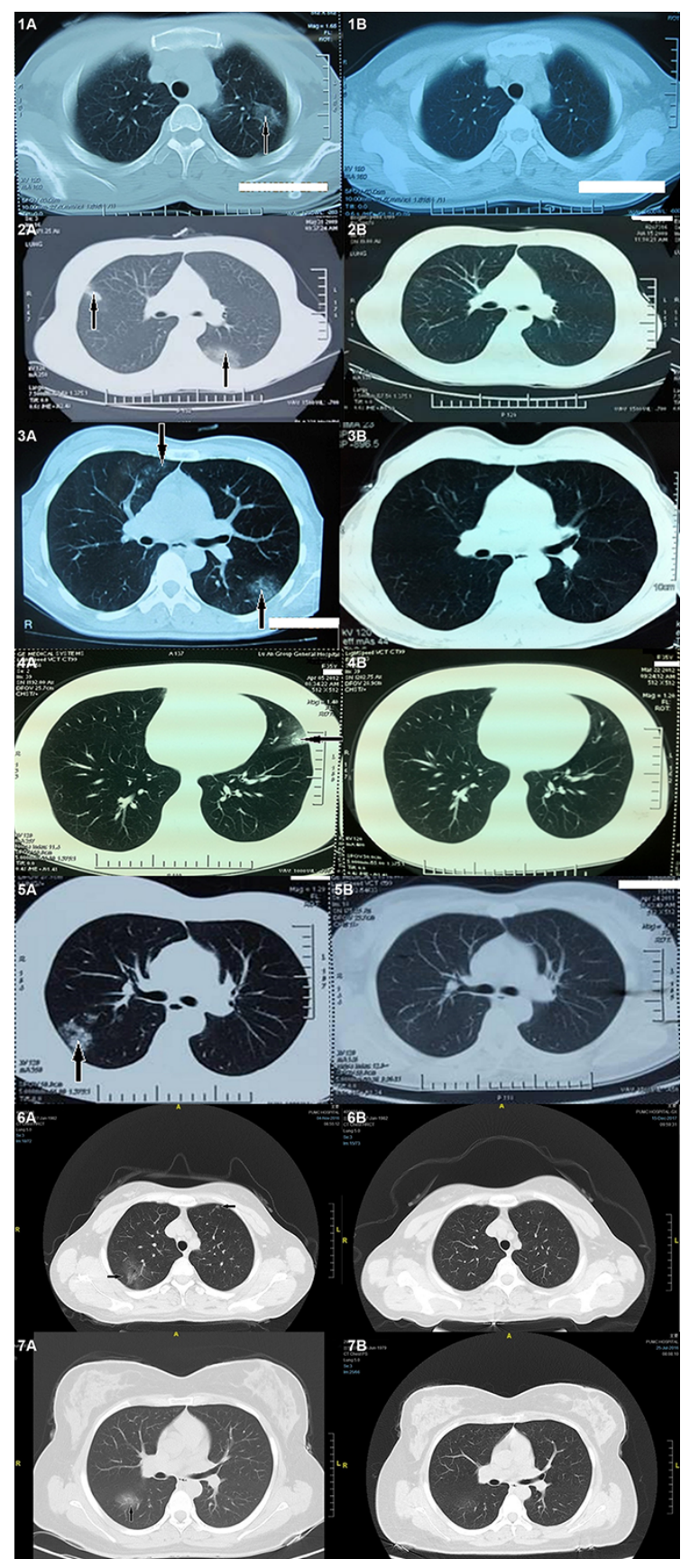

Figure 1

CT scan of the chest of $\mathrm{CH}$ patients $1,2,3,4,5,6$ and 7 during menstruation (A) and 2 or 3 weeks after menstruation (B). 